\title{
Effect of Long Road Transport Journey on Serum Biomarkers of Bone Formation and Resorption in Athletic Horses
}

\author{
Mohamed Tharwat ${ }^{1,2, *}$ and Fahd Al-Sobayil ${ }^{1}$ \\ ${ }^{1}$ Department of Veterinary Medicine, College of Agriculture and Veterinary Medicine, Qassim University, P.O. Box \\ 6622, Buraidah, 51452, Saudi Arabia \\ ${ }^{2}$ Department of Animal Medicine, Faculty of Veterinary Medicine, Zagazig University, Egypt \\ *Corresponding author: mohamedtharwat129@gmail.com
}

\begin{tabular}{|c|c|c|}
\hline Article History: 21-347 & Revised: 02-Aug-21 & Accepted: 26-Aug-21 \\
\hline \multicolumn{3}{|l|}{ ABSTRACT } \\
\hline $\begin{array}{l}\text { We carried out this study } \\
\text { formation and resorption } \mathrm{b} \\
\text { alkaline phosphatase }(\beta-\mathrm{A} \\
\text { horses were transported fo } \\
\text { after }(\mathrm{T} 1) \text {, and } 24 \mathrm{~h} \text { of off } \\
\text { concentration of } \mathrm{OC} \text { at } \mathrm{T} 1 \\
\text { non-significant at } \mathrm{T} 2(15 \text {. } \\
\text { time points }(\mathrm{T} 0=28.79 \pm 10 \\
\text { increased at } \mathrm{T} 1(10.32 \pm 4 \\
\text { conclusion, the transportat } \\
\text { turnover. This might indic }\end{array}$ & $\begin{array}{l}\text { investigate the effects of a } 300 \mathrm{~km} \text { road transport jo } \\
\text { arkers in athletic horses. The bone formation biomark } \\
\text { and the bone resorption biomarker included pyridino } \\
0 \mathrm{~km} \text { on a paved road at } 100 \mathrm{~km} / \mathrm{h} \text {. Sera were harveste } \\
\text { ing (T2) and stored at }-30^{\circ} \mathrm{C} \text {. The results showed sig } \\
7.05 \pm 2.12 \mathrm{ng} / \mathrm{mL}) \text { compared to its levels at T0 }(12.95 \\
3.99 \mathrm{ng} / \mathrm{mL}) \text {. The serum concentrations of } \beta \text {-ALP di } \\
\mathrm{J} / \mathrm{L}, \mathrm{T} 1=33.28 \pm 12.76 \mathrm{U} / \mathrm{L}, \mathrm{T} 2=29.12 \pm 10.59 \mathrm{U} / \mathrm{L}) \text {. The } \\
\mathrm{mol} / \mathrm{L}) \text { compared to its levels at } \mathrm{T} 0(6.81 \pm 1.59 \mathrm{nmo} \\
\text { of horses for } 300 \mathrm{~km} \text { at a speed of } 100 \mathrm{~km} / \mathrm{h} \text { significan } \\
\text { a significant alteration that occurred in bone metaboli }\end{array}$ & $\begin{array}{l}\text { the serum levels of bone } \\
\text { ded osteocalcin (OC), bone } \\
\text { s-links (PYD). Ten athletic } \\
\text { transport (T0), immediately } \\
\text { higher levels in the serum } \\
\text { (mL), and its value became } \\
\text { fer among the tested three- } \\
\text { ration of PYD significantly } \\
\text { T2 ( } 6.46 \pm 1.03 \text { nmol/L). In } \\
\text { sed the biomarkers of bone } \\
\text { g transportation. }\end{array}$ \\
\hline
\end{tabular}

Key words: Bon; Biomarkers; $\beta$-ALP; Horses; Osteocalcin; Pyridinoline.

\section{INTRODUCTION}

In many countries around the world, appropriate handing of animals during transport is given more attention by those interested in this field (Sporer et al. 2008). In large animals, it is well known that transport has many stressors, including but not limited to dealing, loading, unloading, harsh weather, bad ventilation, and shortage of food and water (Padalino 2015). Transportation by trucks is a recognized stressor that has reverse effects on the production and health of livestock (Tharwat et al. 2013). Regrettably, the dealing, loading and unloading of animals constitute the most stressor during transportation (Minka et al. 2009).

Bone biomarkers are broadly used in human medicine, mainly for observation of bone response to treatment of special musculoskeletal diseases (Sabour et al. 2014). In veterinary field, the biomarkers of bone are commonly used in animals as a quick and sensible mean for evaluation of bone reaction to medical therapy and invasive interference, and for the diagnosis of musculoskeletal problems (AlSobayil and Tharwat 2021). The commonly used bone formation markers are osteocalcin (OC) and bone alkaline phosphatase ( $\beta$-ALP). However, the most commonly used bone resorption markers are pyridinoline cross-links (PYD) and deoxypyridinoline (Al-Sobayil and Tharwat 2021).

As other animals, horses are transported by different means such as shipping, train, road and also by air. During such event, significant changes occur such as variability in heart rate, cardiac biomarkers, cortisol, lactate, and hemato-biochemical variables. It has been therefore suggested that transportation is stressful for horses on the basis of high cortisol levels and changes in the heart rate (Tharwat and Al-Sobayil 2014). This investigation was designed to highlight the influence of a $300 \mathrm{~km}$ road transport on the serum levels of bone turnover biomarkers in athletic horses.

\section{MATERIALS AND METHODS}

\section{Ethical Approval and Transportation of Horses}

Animal Ethical Committee, Scientific Research Deanship in the University of Qassim, Saudi Arabia

Cite This Article as: Tharwat M and Al-Sobayil F, 2022. Effect of long road transport journey on serum biomarkers of bone formation and resorption in athletic horses. International Journal of Veterinary Science 11(2): 268-271. https://doi.org/10.47278/journal.ijvs/2021.090 
Int J Vet Sci, 2022, 11(2): 268-271.

approved this study. The study design has been reported previously (Tharwat and Al-Sobayil 2014). Briefly, 10 athletic Arabian horses aged 9.8 \pm 2.3 years and weighed $345 \pm 21 \mathrm{~kg}$ were used in the study. On a paved road, transport of the horses has been performed between 15:00 to 20:00 hours with an ambient temperature of $25^{\circ} \mathrm{C}$ and a relative humidity of $60 \%$. Two trucks were used, 5 horses each at a density of $1.2 \times 3.0 \mathrm{~m}$ for a journey of $300 \mathrm{~km}$. No tranquilizers were used throughout the transportation.

\section{Blood Sampling and Assays of Bone Biomarkers}

From each horse, 3 serum samples were collected and stored at $-30^{\circ} \mathrm{C}$ (before transport, T0; immediately after transport, $\mathrm{T} 1 ; 24 \mathrm{~h}$ of transport, $\mathrm{T} 2$ ). The serum concentrations of OC, $\beta$-ALP and PYD were evaluated using immunoassay kits as reported (Tharwat et al. 2014; Tharwat and Al-Sobayil 2015, 2018a,b; Tharwat 2020a,b; Al-Sobayil and Tharwat 2021).

\section{Statistical Analysis}

Assessment of data normality was carried out using D'Agostino Pearson test. Data were presented as mean \pm SD as there was no significant deviation from normality. Statistical analysis was performed using the SPSS-program version 25.0 (SPSS 2017). Multiple comparisons among the 3 time points (T0, T1 and T2) were carried using the Dunnett's test and the significance value was set at $\mathrm{P} \leq 0.05$.

\section{RESULTS}

After unloading of the horses, none of them developed any abnormality such as depression or loss of appetite. In Fig. 1, levels of bone formation (OC, $\beta$-ALP) and bone resorption (PYD) biomarkers in serum were displayed. Compared to a mean value of $12.95 \pm 1.92 \mathrm{ng} / \mathrm{mL}$ before transport (T0), the OC value increased immediately after unloading (T1) where it was measured $17.05 \pm 2.12 \mathrm{ng} / \mathrm{mL}$ with a statistically significant difference between them $(\mathrm{P}=0.001)$. Twenty-four hours after transport (T2), the OC serum values were tested $15.33 \pm 3.99 \mathrm{ng} / \mathrm{mL}$ with a nonsignificant difference when compared to values pre- or immediately after transport $(\mathrm{P}=0.15,0.30$, respectively). The serum concentrations of $\beta$-ALP did not change significantly at the 3 time points. At T0, T1 and T2 it measured 28.79 $\pm 10.39 \mathrm{U} / \mathrm{L}, 33.28 \pm 12.76 \mathrm{U} / \mathrm{L}, 29.12 \pm 10.59$ $\mathrm{U} / \mathrm{L}$, respectively $(\mathrm{P}>0.05)$. Compared to a mean value of $6.81 \pm 1.59 \mathrm{nmol} / \mathrm{L}$ before loading (T0), the PYD levels increased significantly after transport where it measured $10.32 \pm 4.39 \mathrm{nmol} / \mathrm{L}(\mathrm{P}=0.05)$. At T2, the PYD serum values were measured $6.46 \pm 1.03 \mathrm{nmol} / \mathrm{L}$, with a significant change when compared to $\mathrm{T} 1(\mathrm{P}=0.03)$, but with a non-significant level when compared to T0 $(\mathrm{P}=0.61)$.

\section{DISCUSSION}

In the horse, a $12 \mathrm{~h}$ journey resulted in significantly increased levels in the stress biomarker malondialdehyde compared to pre-transport levels (Onmaz et al. 2011). Similar, an eight-hour road transport in the horse elevated the plasma total antioxidant values just after transport end (Niedźwiedź et al. 2013). This clearly indicates that transportation is stressful for horses. A question of what the effects of horse transportation on the bone biomarkers will

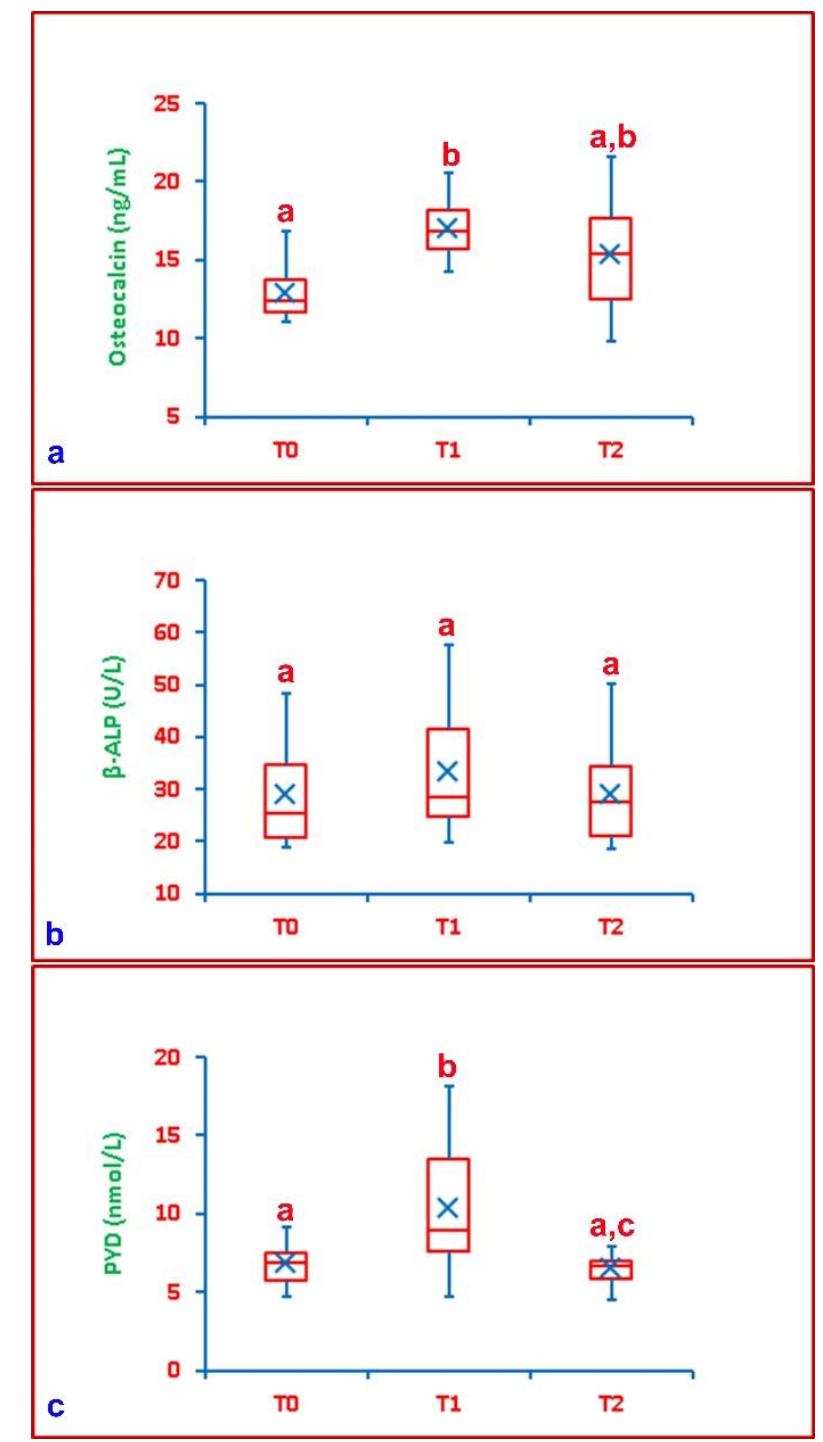

Fig. 1: Box and whiskers plot of the bone biomarkers osteocalcin (a), $\beta$-alkaline phosphatase ( $\beta$-ALP; b) and pyridinoline crosslinks (PYD; c) in 10 horses enrolled in a $300 \mathrm{~km}$ transport journey. T0, immediately before transport; T1, just before transport; T2, 24 hours after transport. ${ }^{\text {a,b,c }}$ different letters indicate a significant difference $(\mathrm{P} \leq 0.05)$.

be was raised. Therefore, this study was carried out trying to answer this question. It is believed that ongoing research on bone biomarkers will be increasingly used in the future in the diagnosis and prognosis of musculoskeletal and bone injuries in horses. These bone formation and bone resorption biomarkers are biochemical by-products that provide insight into the activity of bone cells and are created from the bone remodeling process (Allen 2003).

Osteocalcin is the most plentiful protein in bone that is particularly expressed in osteoblasts (Komori 2020). A recent unexpected development of bone biology reported that $\mathrm{OC}$ is not only a bone remodeling marker but also an active hormone contributing to the organization of a number of physiological processes. Of these functions regulated by OC is glucose homeostasis (Wei and Karsenty 2015). Knowledge about the hormone OC has therefore significantly expanded the area of bone biology because of the physiologic operation adjusted by this hormone such as metabolism of energy and growth of the brain (Karsenty 2017). Clinically, OC is a biomarker of bone formation, 
and an exercise increase this process and also improves glucose metabolism, making a link between OC and glucose metabolism (Al-Sobayil and Tharwat 2021).

In this study, transportation of horses for $300 \mathrm{~km}$ increased the serum OC to significant levels immediately after unloading compared to pre-transport levels. The OC values remained high $24 \mathrm{~h}$ after transport compared to preloading measurements but didn't reach the significant levels. Increases in serum OC levels after transport in this study may be clinically important. Results from human studies demonstrated that exercise training induces significant increases in serum levels of OC; possibly due to some influences such as increasing the insulin sensitivity, beside its direct effect on bone osteoblastic activity (Rahimi et al. 2021). Elevation in insulin sensitivity may be caused by muscle contraction during road transport, similar to exercise (Rahimi et al. 2021).

The enzyme alkaline phosphatase has 2 types; the first is tissue-specific and the second is tissue non-specific). The intestine, placenta, and germinal tissue contain the first type. However, the second type is principally expressed in bone, liver and kidney, and it plays a core role in bone calcification (Vimalraj 2020). On the surface of osteoblasts, the $\beta$-ALP is found, and has been shown to be a sensible index of bone formation. Approximately, half of the ALP is produced from bone in animals with healthy liver. The correlation between $\beta$-ALP and OC in the blood was reported to be weak although both are bone formation markers (Al-Sobayil and Tharwat 2021). This was evident in the results of this study as the serum values of OC increased significantly after transport, nevertheless $\beta$-ALP did not differ significantly among values measured immediately before and after transport, and $24 \mathrm{~h}$ of the end of transport.

The bone resorption biomarker PYD is not only presented in mature type I collagen, which is the main type of collagen in bone tissues, but also in collagen types II and III (Al-Sobayil and Tharwat 2021). The PYD is manufactured during ripeness of collagens and freed into the blood from degeneration of this grown collagens (Kuo and Chen 2017). Increased levels of PYD in the blood or urine are mostly believed as an indicator of bone resorption (Thompson et al. 1992). In this study, the serum levels of PYD increased significantly after transport compared to values before loading but it declined $24 \mathrm{~h}$ later to values close to that before transport. The increased PYD in this study suggests excessive bone resorption as a result of road transportation in the horses. The clear product of bone formation and resorption is called bone mass, which are firmly adjusted by the balance between endogenous/ and exogenous factors (Lombardi et al. 2012). These bone turnover markers are very reactive to exercise varying according to the type of exercise (Gombos et al. 2016). Forces produced by muscle contractility make significant functions in motivating the response of skeletal system to the mechanical process of loading (Kohrt et al. 2009).

\section{Conclusion}

It is concluded that transportation of horses for $300 \mathrm{~km}$ round trip journey did not change significantly the bone formation biomarker OC and $\beta$-ALP after transport. However, the bone resorption biomarker PYD increased significantly after transport compared to values before loading. This might be an indication to a significant alteration occurred in bone metabolism during transportation. What will be the potential effects on bone metabolism biomarkers if horses are transported for longer distances and were exposed to more stressful conditions? A future study is therefore warranted to answer this question.

\section{Author's Contribution}

Both authors planned the study and carried out the practical work. M. Tharwat wrote the original draft and made the figure. F. Al-Sobayil read and revised the manuscript. Both authors have read and approved the manuscript.

\section{REFERENCES}

Allen MJ, 2003. Biochemical markers of bone metabolism in animals: Uses and limitations. Veterinary Clinical Pathology 32: 101-113. https://doi.org/10.1111/j.1939-165x.2003. tb00323.x

Al-Sobayil F and Tharwat M, 2021. Effects of acute synovitis experimentally induced by amphotericin-B on the biomarkers of camel joint structures. Journal of Camel Practice and Research 28: 169-174. https://doi.org/10.5958/ 2277-8934.2021.00027.8

Gombos GC, Bajsz V, Pék E, Schmidt B, Sió E, Molics B and Betlehem J, 2016. Direct effects of physical training on markers of bone metabolism and serum sclerostin concentrations in older adults with low bone mass. BMC Musculoskeletal Disorders 17: 254. https://doi.org/10.1186/ s12891-016-1109-5

Karsenty G, 2017. Update on the biology of osteocalcin. Endocrine Practice 23: 1270-1274. https://doi.org/10.4158/ EP171966.RA

Kohrt WM, Barry DW and Schwartz RS, 2009. Muscle forces or gravity: what predominates mechanical loading on bone? Medicine \& Science in Sports \& Exercise 41: 2050-2055. https://doi.org/10.1249/MSS.0b013e3181a8c4b6

Komori T, 2020. What is the function of osteocalcin? Journal of Oral Biosciences 62: 223-227. https://doi.org/10.1016/j. job.2020.05.004

Kuo $\mathrm{T}$ and Chen $\mathrm{C}, 2017$. Bone biomarker for the clinical assessment of osteoporosis: recent developments and future perspectives. Biomarker Research 5: 18. https://doi.org/ 10.1186/s40364-017-0097-4

Lombardi G, Lanteri P, Colombini A, Mariotti M and Banfi G, 2012. Sclerostin concentrations in athletes: role of load and gender. Journal of Biological Regulators and Homeostatic Agents 26: 157-163.

Minka NS, Ayo JO, Sackey AKB and Adelaiye AB, 2009 Assessment and scoring of stresses imposed on goats during handling, loading, road transportation and unloading, and the effect of pretreatment with ascorbic acid. Livestock Science 125: 275-282. https://doi.org/ 10.1016/j.livsci.2009.05.006

Niedźwiedź A, Kubiak K and Nicpoń J, 2013. Plasma total antioxidant status in horses after 8-hours of road transportation. Acta Veterinaria Scandinavica 55: 58. https://doi.org/10.1186/1751-0147-55-58

Onmaz AC, Van Den Hoven R, Gunes V, Cinar M and Kucuk O, 2011. Oxidative stress in horses after a 12-hours transport period. Revue de Médecine Vétérinaire 162: 213-217.

Padalino B, 2015. Effects of the different transport phases on equine health status, behavior and welfare: A review. Journal of Veterinary Behavior 10: 272-282. https://doi.org/10.1016/ j.jveb.2015.02.002

Rahimi M, Niyazi A and Alaee S, 2021. The effect of exercise training on osteocalcin, adipocytokines, and insulin 
Int J Vet Sci, 2022, 11(2): 268-271.

resistance: a systematic review and meta-analysis of randomized controlled trials. Osteoporosis International 32: 213-224. https://doi.org/10.1007/s00198-020-05592-w

Sabour H, Norouzi Javidan A, Latifi S, Larijani B, Shidfar F, Vafa MR, Heshmat R and Emami Razavi H, 2014. Bone biomarkers in patients with chronic traumatic spinal cord injury. Spine Journal 14: 1132-1138. https://doi.org/ 10.1016/j.spinee.2013.07.475

Sporer BKR, Weber PSD, Burton JL and Crowe MA, 2008. Transportation of young beef bulls alters circulating physiological parameters that may be effective biomarkers of stress. Journal of Animal Science 86: 1325-1334. https://doi.org/10.2527/jas.2007-0762

SPSS, 2017. Statistical Package for Social Sciences, SPSS Inc., Chicago, IL, USA Copyright $\odot$ for Windows, version 25.

Tharwat M, Al-Sobayil F and Buczinski S, 2013. Cardiac biomarker changes in camels (Camelus dromedarius) secondary to road transportation. Journal of Veterinary Cardiology 15: 115-122. https://doi.org/10.1016/j.jvc.2012. $\underline{08.004}$

Tharwat M and Al-Sobayil F, 2014. Influence of transportation on serum concentration of the cardiac biomarkers troponin I and creatine kinase myocardial band in horses. Journal of Equine Veterinary Science 34: 662-667. https://doi.org/10.1016/ j.jevs.2013.12.008

Tharwat M, Al-Sobayil F and Buczinski S, 2014. Influence of racing on the serum concentrations of acute phase proteins and bone metabolism biomarkers in racing greyhounds. The Veterinary Journal 202: 372-377. https://doi.org/10.1016/ j.tvjl.2014.08.027

Tharwat M and Al-Sobayil F, 2015. Serum concentrations of acute phase proteins and bone biomarkers in female dromedary camels during the periparturient period. Journal of Camel Practice and Research 22: 271-278 https://doi.org/10.5958/2277-8934.2015.00045.4

Tharwat M, 2020a. Inflammation and bone biomarkers in healthy dromedary camels with isoflurane or halothane general anesthesia. Journal of Camel Practice and Research 27: 295 300. https://doi.org/10.5958/2277-8934.2020.00023.5

Tharwat M, 2020b. Serum concentration of bone metabolism biomarkers in goats during the transition period. Veterinary Medicine International 2020: 4064209. https://doi.org/ 10.1155/2020/4064209

Tharwat M and Al-Sobayil F, 2018a. Influence of electroejaculator on serum concentrations of acute phase proteins and bone metabolism biomarkers in male dromedary camels (Camelus dromedarius). Journal of Applied Animal Research 46:1226-1232. https://doi.org/ 10.1080/09712119. 2018.1490299

Tharwat $\mathrm{M}$ and $\mathrm{Al}-$ Sobayil $\mathrm{F}, 2018 \mathrm{~b}$. The impact of racing on serum concentrations of bone metabolism biomarkers in racing Arabian camels. Journal of Camel Practice and Research 25: 59-63. https://doi.org/10.5958/2277-8934. 2018.00009.7

Thompson PW, Spector TD, James IT, Henderson E and Hart DJ, 1992. Urinary collagen crosslinks reflect the radiographic severity of knee osteoarthritis. British Society for Rheumatology 31: 759-761. https://doi.org/10.1093/rheuma tology/31.11.759

Vimalraj S, 2020. Alkaline phosphatase: Structure, expression and its function in bone mineralization. Gene 754: 144855 https://doi.org/10.1016/i.gene.2020.144855

Wei $\mathrm{J}$ and Karsenty G, 2015. An overview of the metabolic functions of osteocalcin. Rev Reviews in Endocrine and Metabolic Disorders 16: 93-98. https://doi.org/10.1007/ $\underline{\text { s11154-014-9307-7 }}$ 